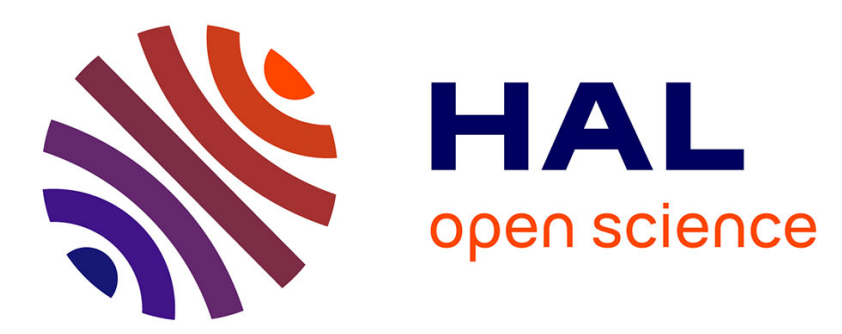

\title{
Screening of antibiotic residues in ewe milk destined to cheese by a commercial microbiological inhibition assay
}

Miho Yamaki, M. Isabel Berruga, Rafael Lisandro Althaus, Pilar Molina, Ana Molina

\section{- To cite this version:}

Miho Yamaki, M. Isabel Berruga, Rafael Lisandro Althaus, Pilar Molina, Ana Molina. Screening of antibiotic residues in ewe milk destined to cheese by a commercial microbiological inhibition assay. Food Additives and Contaminants, 2006, 23 (07), pp.660-667. 10.1080/02652030500428655 . hal00578285

\section{HAL Id: hal-00578285 \\ https://hal.science/hal-00578285}

Submitted on 19 Mar 2011

HAL is a multi-disciplinary open access archive for the deposit and dissemination of scientific research documents, whether they are published or not. The documents may come from teaching and research institutions in France or abroad, or from public or private research centers.
L'archive ouverte pluridisciplinaire HAL, est destinée au dépôt et à la diffusion de documents scientifiques de niveau recherche, publiés ou non, émanant des établissements d'enseignement et de recherche français ou étrangers, des laboratoires publics ou privés. 


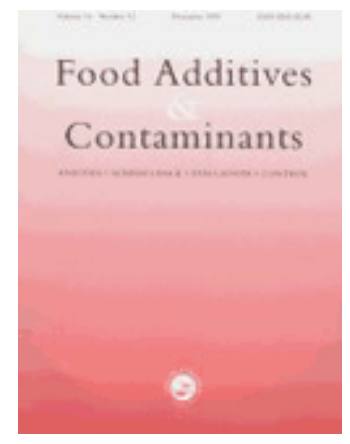

\section{Screening of antibiotic residues in ewe milk destined to cheese by a commercial microbiological inhibition assay}

\begin{tabular}{|r|l|}
\hline Journal: & Food Additives and Contaminants \\
\hline Manuscript ID: & TFAC-2005-246 \\
\hline Manuscript Type: & Original Research Paper \\
\hline Author: & $29-$ Aug-2005 \\
\hline Complete List of Authors: & $\begin{array}{l}\text { Yamaki, Miho; Universidad de Castilla-La Mancha, Ciencia y } \\
\text { Tecnología Agroforestal; Universidad de Castilla-La Mancha, Seccion } \\
\text { Calidad Alimentaria. Instituto de Desarrollo Regional } \\
\text { Berruga, M. Isabel; Universidad de Castilla-La Mancha, Seccion } \\
\text { Calidad Alimentaria. Instituto de Desarrollo Regional; Universidad } \\
\text { de Castilla-La Mancha, Ciencia y Tecnología Agroforestal } \\
\text { Althaus, Rafael; Universidad Nacional del Litoral, Facultad de } \\
\text { Veterinaria } \\
\text { Molina, Pilar; Universidad Politécnica de Valencia, Ciencia Animal } \\
\text { Molina, Ana; Universidad de Castilla-La Mancha, Seccion Calidad } \\
\text { Alimentaria. Instituto de Desarrollo Regional; Universidad de } \\
\text { Castilla-La Mancha, Ciencia y Tecnología Agroforestal }\end{array}$ \\
\hline Methods/Techniques: & Screening - microbial screening, Eclipse "100"ov \\
\hline Additives/Contaminants: & Veterinary drug residues - antibiotics \\
\hline Food Types: & ewe milk quality \\
\hline
\end{tabular}

\section{SCHOLARONE" Manuscripts}


Table 1. Summary of the logistic regression model coefficients for the initial analysis by Eclipse "100ov" ${ }^{\circledR}$ test.

\begin{tabular}{|c|c|c|}
\hline Parameter & " $\chi^{2 \text { "v value }}$ & "p" value \\
\hline Month $^{1}$ & 0,5553 & 0.4561 \\
\hline Month $^{2}$ & 6.7130 & 0.0096 \\
\hline Month $^{3}$ & 5.7118 & 0.0169 \\
\hline Month $^{4}$ & 4.9877 & 0.0255 \\
\hline $\mathrm{SCC}$ & 0.1084 & 0.7419 \\
\hline Bacteriology & 0.4872 & 0.4852 \\
\hline Fat & 1.3921 & 0.2380 \\
\hline Protein & 0.8476 & 0.3572 \\
\hline
\end{tabular}


Table 2. Summary of the logistic regression model coefficients for the confirmation after heating at $82^{\circ} \mathrm{C} 10 \mathrm{~min}$ by Eclipse “100ov" ${ }^{\circledR}$ test.

\begin{tabular}{|c|c|c|}
\hline Parameter & " $\chi^{2 \text { "v value }}$ & "p" value \\
\hline Month $^{1}$ & 5.5057 & 0.0190 \\
\hline Month $^{2}$ & 5.6101 & 0.0179 \\
\hline Month $^{3}$ & 5.2028 & 0.0226 \\
\hline Month $^{4}$ & 4.7081 & 0.0300 \\
\hline $\mathrm{SCC}$ & 0.2387 & 0.6251 \\
\hline Bacteriology & 1.3681 & 0.2421 \\
\hline Fat & 2.7231 & 0.0989 \\
\hline Protein & 0.0844 & 0.7714 \\
\hline
\end{tabular}


Table 3. Identification of "positive and doubtful" samples (absolute and relative frequencies) after the PABA and penicillinase tests.

\begin{tabular}{lcc}
\hline Compound & Absolute frequency & Relative frequency $(\%)$ \\
\hline Non Identified Substance & 19 & 73 \\
$\beta$-lactam & 6 & 23 \\
Sulphonamide & - & - \\
$\beta$-lactam and sulphonamide & - & - \\
Diluted Samples & 1 & 4 \\
Total & 26 & 100 \\
\hline
\end{tabular}


Table 4. Data comparison of Eclipse “100ov" ${ }^{\circledR}$ results with Delvotest $S P^{\circledR} *$ results after initial analysis.

\begin{tabular}{|c|c|c|c|c|c|c|}
\hline \multirow{2}{*}{\multicolumn{2}{|c|}{ Results }} & \multicolumn{3}{|c|}{ Eclipse“100ov" ${ }^{\circledR}$} & \multirow{2}{*}{$" \chi^{2 ،}$} & \multirow{2}{*}{ "p" value } \\
\hline & & Positives & Negatives & Total & & \\
\hline \multirow{3}{*}{ Delvotest $\mathrm{SP}^{\circledR}$} & Positives & $\begin{array}{c}46 \\
(1.71 \%)\end{array}$ & $\begin{array}{c}55 \\
(2.05 \%)\end{array}$ & $\begin{array}{c}101 \\
(3.76 \%)\end{array}$ & \multirow{3}{*}{750.56} & \multirow{3}{*}{0.0000} \\
\hline & Negatives & $\begin{array}{c}25 \\
(0.93 \%)\end{array}$ & $\begin{array}{c}2560 \\
(95.31 \%)\end{array}$ & $\begin{array}{c}2585 \\
(96,24 \%)\end{array}$ & & \\
\hline & Total & $\begin{array}{c}71 \\
(2.64 \%)\end{array}$ & $\begin{array}{c}2615 \\
(97.36 \%)\end{array}$ & $\begin{array}{c}2686 \\
(100 \%)\end{array}$ & & \\
\hline
\end{tabular}

* Data for comparing from Yamaki et al. (2004). 
Table 5. Data comparison of Eclipse “100ov" ${ }^{\circledR}$ results with Delvotest $S P^{\circledR} *$ results after confirmation analysis after heating at $82^{\circ} \mathrm{C} 10 \mathrm{~min}$.

\begin{tabular}{|c|c|c|c|c|c|c|}
\hline \multirow{2}{*}{\multicolumn{2}{|c|}{ Results }} & \multicolumn{3}{|c|}{ Eclipse“100ov" ${ }^{\circledR}$} & \multirow{2}{*}{$" \chi^{2 *}$} & \multirow{2}{*}{ "p" value } \\
\hline & & Positives & Negatives & Total & & \\
\hline \multirow{3}{*}{ Delvotest $\mathrm{SP}^{\circledR}$} & Positives & $\begin{array}{c}17 \\
(0.63 \%)\end{array}$ & $\begin{array}{c}30 \\
(1.12 \%)\end{array}$ & $\begin{array}{c}47 \\
(1.75 \%)\end{array}$ & \multirow{3}{*}{644} & \multirow{3}{*}{0.0000} \\
\hline & Negatives & $\begin{array}{c}9 \\
(0.34 \%)\end{array}$ & $\begin{array}{c}2630 \\
(97.92 \%)\end{array}$ & $\begin{array}{c}2639 \\
(98,25 \%)\end{array}$ & & \\
\hline & Total & $\begin{array}{c}26 \\
(0.97 \%)\end{array}$ & $\begin{array}{c}2660 \\
(99.03 \%)\end{array}$ & $\begin{array}{c}2686 \\
(100 \%)\end{array}$ & & \\
\hline
\end{tabular}

* Data for comparing from Yamaki et al. (2004). 
Table 6. Data comparison of Eclipse “100ov" ${ }^{\circledR}$ with Delvotest $S P^{\circledR} *$ positive and false positive results.

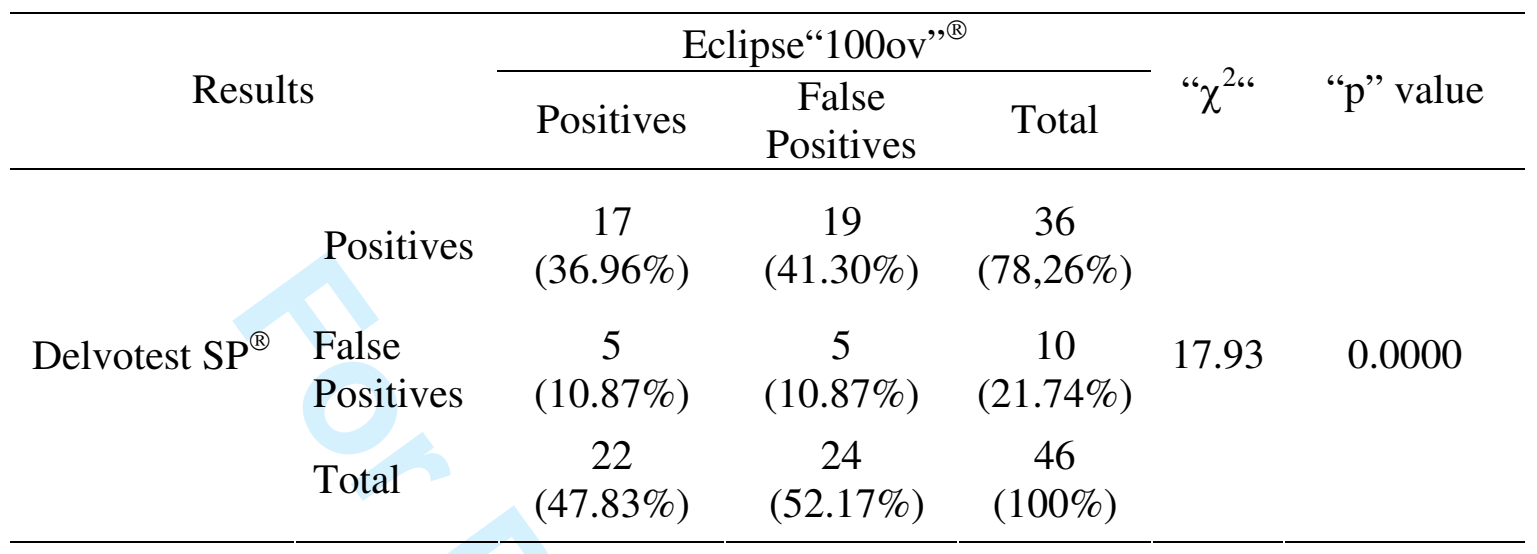

* Data for comparing from Yamaki et al. (2004). 
Figure 1. "Positive and doubtful" rate (\%) in ewe milk samples at the initial analysis and at the confirmation analysis after 24 hours (heated at $82^{\circ} \mathrm{C}$ for $10 \mathrm{~min}$ ) by Eclipse “100ov" ${ }^{\circledR}$ from July 2002 to June 2003. (•) Real values. ( - ) Predicted values.

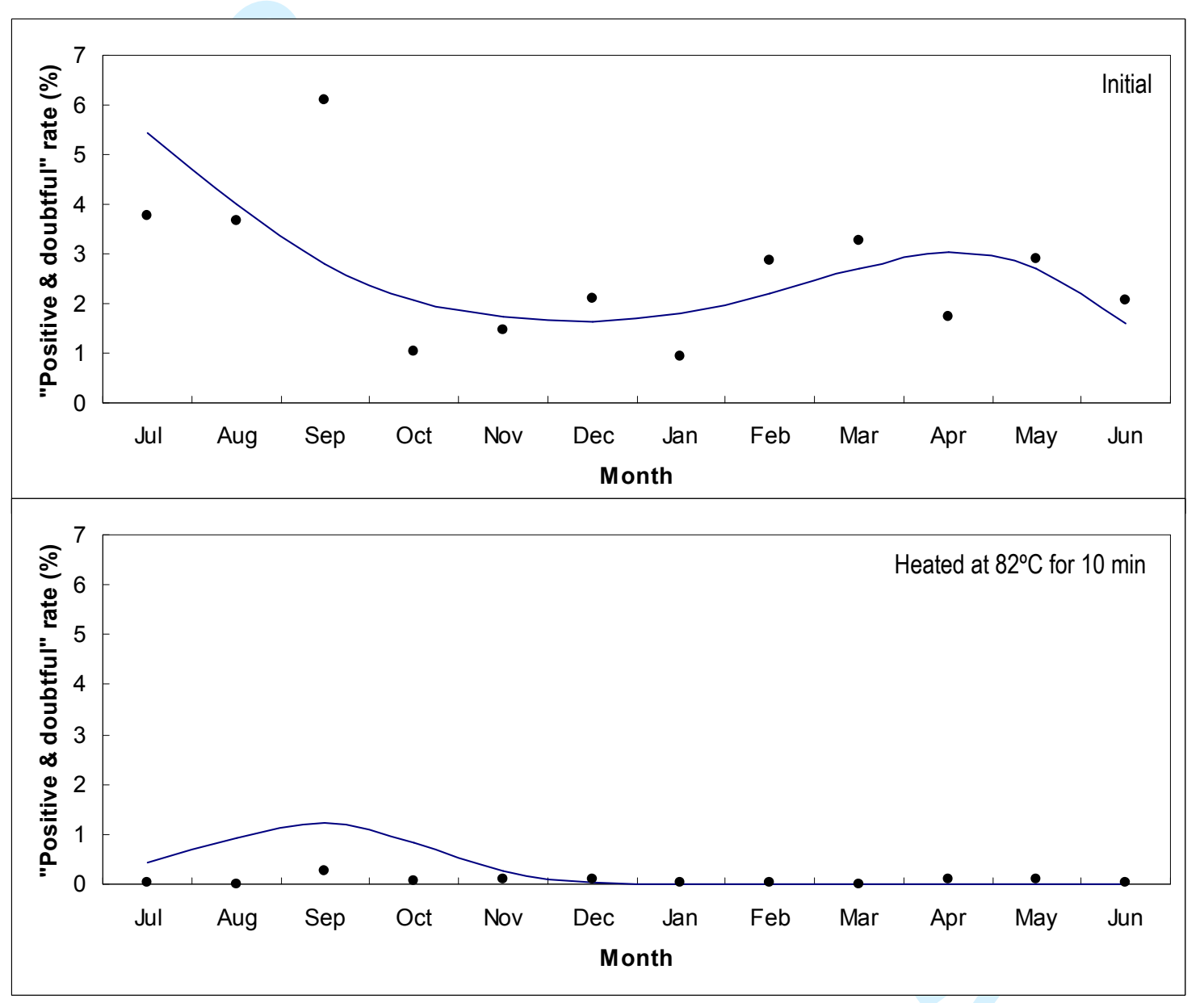


Figure 2. Monthly relative frequencies (\%) of "false positive" samples by the Delvotest $S P^{\circledR}(\mathbf{\square} ; n=54)$ and Eclipse “100ov" ${ }^{\circledR}(\square ; n=45)$ methods.

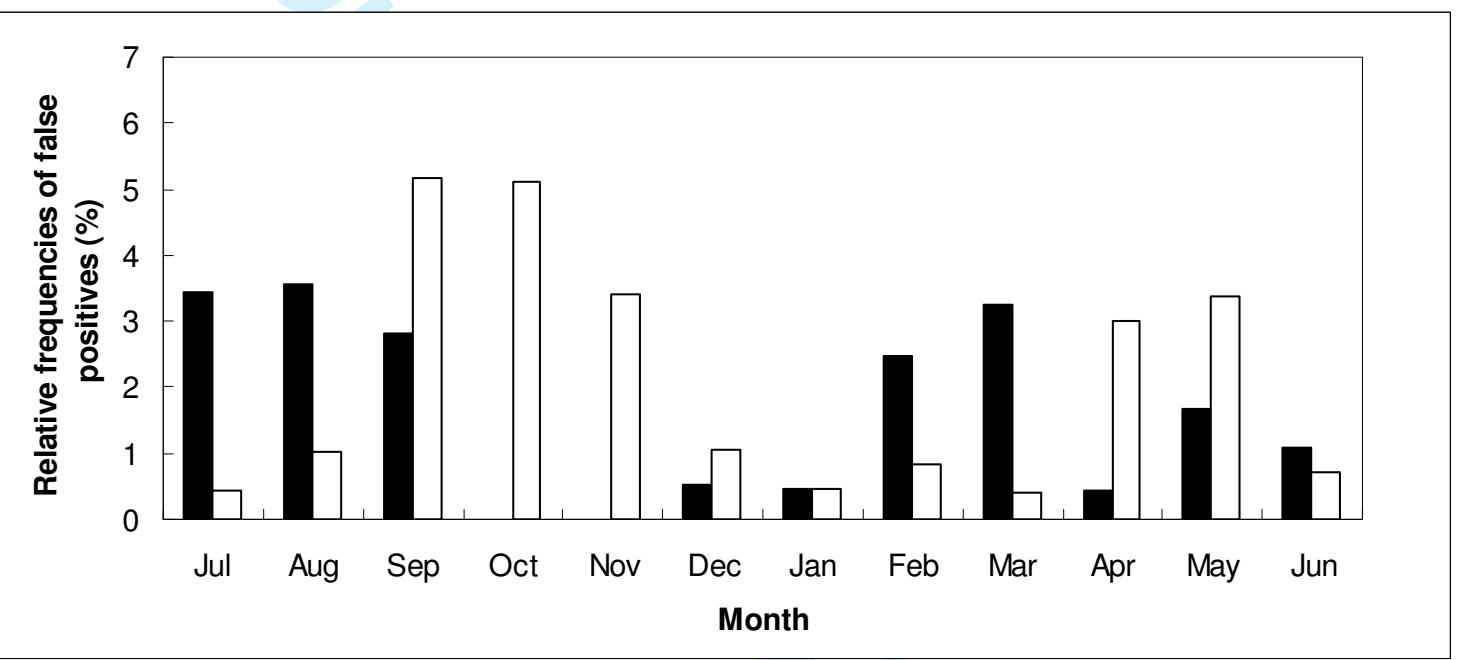




\title{
Screening of antibiotic residues in ewe milk destined to cheese by a commercial microbiological inhibition assay
}

\author{
M. YAMAKI $\dagger \ddagger$, M.I. BERRUGA $\dagger \ddagger *$, R.L. ALTHAUS $\S$, M.P. MOLINA\# and A. \\ MOLINA $\dagger+$ \\ $\dagger$ Departamento de Ciencia y Tecnología Agroforestal, ETSIA, Universidad de Castilla- \\ La Mancha, 02071 Albacete, Spain \\ $\ddagger$ Seccion de Calidad Alimentaria, Instituto de Desarrollo Regional, Universidad de \\ Castilla-La Mancha, 02071 Albacete, Spain \\ $\S C a ́ t e d r a$ de Biofísica, Facultad de Ciencias Veterinarias, Universidad Nacional del \\ Litoral, 3080 Esperanza, Argentina \\ \#Departamento de Ciencia Animal, Universidad Politécnica, 46071 Valencia, Spain
}

*To whom correspondence should be addressed. e-mail: mariaisabel.berruga@uclm.es 


\begin{abstract}
Bulk ewes milk from Spanish dairy farms situated in the Castilla-La Mancha region, and destined for production of Protected Denomination of Origin (PDO) Manchego cheese, were analysed each month for antimicrobial residues during the course of one year. For this study a microbiological assay specific for ewes milk (Eclipse "100ov" ${ }^{\circledR}$ ) was used. The number of positive samples by the Eclipse "100ov" ${ }^{\circledR}$ test was $2.6 \%$. A second examination of positives following heat treatment at $82^{\circ} \mathrm{C}$ for $10 \mathrm{~min}$ showed a reduction of up to $0.9 \%$ (in other words $63 \%$ of the samples detected corresponded to “false positives"). Twenty-five percent of the confirmed positives were identified as $\beta$ lactams by a penicillinase solution, the remainder corresponded to antimicrobial compounds that could not be identified. The month of collection was related to the probability of positive results, but no other factors such as somatic cell counts (SCC), bacteriology or composition (fat and protein). The highest rates of positives were observed in September and October. Finally the results were compared with those obtained by the Delvotest $\mathrm{SP}^{\circledR}$ method and showed the detection of a smaller number of positive samples with the Eclipse "100ov" ${ }^{\circledR}$ method.
\end{abstract}

Key words: ewe milk quality, antibiotic residue, screening test, Eclipse "100ov" 


\section{Introduction}

Currently, Spain is the third most important ewe milk producer of the European Union-25 with a turnover of about $16.6 \%$ (FAOSTAT 2004). This production is mainly focused in two regions: Castilla-León and Castilla-La Mancha. Of the two regions, Castilla-La Mancha takes second place (31.9\%) and uses almost all this milk for cheese production (MAPYA 2002a). The Protected Denomination of Origin (PDO) Manchego cheese is very important in this region, since it is the most produced Spanish PDO cheese (43\% of the total PDO cheeses; MAPYA 2002b).

In order to ensure the hygienic-sanitary quality and safety of raw milk the EU established food regulations in the dairy sector (Council Directives 92/46/CEE of 16 June 1992, Council Directives 96/23/EEC of 29 April 1996; Commission Decision 97/747/EC of 27 October 1997). These measures check residues in milk and dairy products, and establish the frequencies and level of sampling, and the groups of substances to be controlled.

In Spain, ewes milk is monitored for antibiotic residues at dairy laboratories by several microbiological screening tests to control the presence of antibiotic residues. Some of these tests are the $\mathrm{BRT}^{\circledR} \mathrm{AiM}$, the Delvotest $\mathrm{SP}^{\circledR}$ or the Eclipse "100ov" ${ }^{\circledR}$ (Barbosa et al. 2004). The detection limits for the main antibiotics used in ovine therapy have been estimated in ewe milk for all these tests (Althaus et al. 2002, Molina et al. 2003a, Montero et al. 2005).

The purpose of our study was to find out the incidence of antimicrobial residues in ewe milk destined to Manchego PDO cheese production by using the Eclipse "100ov" ${ }^{\circledR}$, a 
specific microbiological screening test for ewe milk, as well as the influence of several factors that commonly provoke interferences in the responses of microbial screening tests, such as the somatic cell counts (SCC), bacteriology, composition or seasonality. A second objective was to compare the results obtained by this method with those obtained by the Delvotest $\mathrm{SP}^{\circledR}$ test, a method approved by the Association of Official Analytical Chemists (AOAC).

\section{Materials and methods}

Milk sample collections

Ewe milk samples from bulk tanks were collected on a monthly basis from Manchega ewe flocks which supplied milk for PDO Manchego cheese production, from July 2002 to June 2003. A total of 2686 samples were collected in a $100 \mathrm{~mL}$-disposable plastic container without any preservatives and kept at $4^{\circ} \mathrm{C}$ until they were analysed (no later than 48 hours).

Another sample of milk was collected with $4 \mu \mathrm{l} / \mathrm{mL}$ solution of acidiol (150 mg chloranphenicol, $1 \mathrm{~mL}$ ethanol, $3.5 \mathrm{~g}$ sodium amide, $4.5 \mathrm{~g}$ sodium citrate $5 \mathrm{H}_{2} \mathrm{O}$, in 100 $\mathrm{mL}$ of distilled water) for chemical, bacteria and SCC determinations. Milk bacteria and SCC levels were determined with a Fossomatic 90 (Foss Electric, Hillerød, Denmark) and a BactoScan 8000S (Foss Electric, Hillerød, Denmark), respectively. Chemical composition was determined with a MilkoScan FT 120 (Foss Electric, Hillerød, Denmark).

Antibiotic Microbiological Screening Test 
Milk samples were analysed over_a 48-hour post-collection period by the Eclipse "100ov" ${ }^{\circledR}$ test (ZEU-Inmunotec, Zaragoza, Spain). The method was carried out according to the manufacturer's instructions. The detection limits for the main antibiotics used in dairy ewes have been reported by Montero et al. (2005). Antibioticfree milk samples were used as "negative controls", and were obtained from controlled animals that did not receive any antibiotic treatment or feed for one month. As "positive controls", milk samples with $4 \mu \mathrm{g}$ benzyl penicillin G (Sigma Chemical Co., MO, USA) $\mathrm{kg}^{-1}$ were used. In all tests visual interpretations were carried out by 3 professionals_and evaluated as "negative", "doubtful" or "positive" qualifications. For the statistical calculations, the visual results that presented at least two similar interpretations were considered. The "positive" and "doubtful" responses were grouped as "positive and doubtful" (Suhren et al. 1996) in order to treat these qualitative variables at two levels: "negatives" and "positives and doubtfuls" (from now "positives"). All samples were simultaneously assayed by the Delvotest $\mathrm{SP}^{\circledR}$ method as described by Yamaki et al. (2004).

\begin{abstract}
"Positive" samples were kept refrigerated at $4^{\circ} \mathrm{C}$ and 24 hours later were heated at $82^{\circ} \mathrm{C}$ for $10 \mathrm{~min}$ (Molina et al. 2003b) for confirmation.
\end{abstract}

\title{
Identification of the antibiotics
}

To identify the presence of $\beta$-lactam or sulphonamide compounds "positive" samples after heat confirmation they were tested with the penicillinase and the p-aminobenzoic acid (PABA) solutions. Four $100 \mu$ l-aliquots of each prepared sample were added to four wells of Eclipse "100ov" ${ }^{\circledR}$ test, followed by: $10 \mu \mathrm{l}$ of distilled water, $10 \mu \mathrm{l}$ of penicillinase solution $\left(100,000 \mathrm{IU} \mathrm{mL}^{-1}\right.$; Cod. 9120, AiM-Analytik in Milch 
Produktions-und Vertriebs-GmbH, München, Germany), and $10 \mu \mathrm{l}$ of PABA solution (3 mg mL ${ }^{-1}$; Cod. A-9878, Sigma Chemical Co., MO, USA) respectively. Data interpretation was performed according to the combination of positive and negative results obtained for each series of four wells as mentioned by Yamaki et al. (2004).

\section{Statistical analysis}

To evaluate the influence of the numerical variables of the month of collection, fat, protein, SCC and bacteria on the responses to the Eclipse $100 \mathrm{ov}$ test a stepwise procedure was applied to the logistic regression option of Statgraphics Plus 5.1., taking the model of the variables that presented a value of Chi-squared $\geq 3.94$. to be relevant. The statistical design was carried out with the following logistic model:

$L_{i j k l m n o p}=\beta_{0}+\beta_{1} \mathrm{~T}_{\mathrm{i}}+\beta_{2} \mathrm{~T}^{2}{ }_{\mathrm{j}}+\beta_{3} \mathrm{~T}^{3}{ }_{\mathrm{k}}+\beta_{4} \mathrm{~T}^{4}{ }_{1}+\beta_{5} \mathrm{SCC}_{\mathrm{m}}+\beta_{6} \mathrm{BAC}_{\mathrm{n}}+\beta_{7} \mathrm{~F}_{\mathrm{o}}+\beta_{8} \mathrm{P}_{\mathrm{p}}+$ $\varepsilon_{\mathrm{ijk} k \mathrm{mnop}}$

where $L_{i j k l m n o p}$ is the variable logit, i.e. $\ln P_{i j k l m n o p} / 1-P_{i j k l m n o p} ; P_{i j k l m n o p}$ is the probability of "positive and doubtful" response; $1-P_{i j k l m n o p}$ is the probability of "negative" response; $\beta_{0}$ to $\beta_{8}$ are coefficients estimated for the logistic regression models; $\mathrm{T}_{\mathrm{i}}$ is the effect of month (from 1 to 12 ); $\mathrm{T}^{2}$ is the effect of month squared; $\mathrm{T}^{3}{ }_{\mathrm{k}}$ is the effect month cubed; $\mathrm{T}_{1}^{4}$ is the effect of month quartered; $\mathrm{SCC}_{\mathrm{m}}$ is the effect of somatic cells; $\mathrm{BAC}_{\mathrm{n}}$ is the effect of bacteria; $\mathrm{F}_{\mathrm{o}}$ is the effect of fat; $\mathrm{P}_{\mathrm{p}}$ is the effect of protein; and $\varepsilon_{\mathrm{ijk} k \mathrm{~m} n o \mathrm{p}}$ is the residual error.

A Chi-squared Goodness of Fit Tests was conducted as a rank of correlation between the observed responses and the predicted probabilities.

In order to compare the results obtained by both tests, Delvotest SP and Eclipse 100ov, a cross tabulation option from the Statgraphics Plus 5.1 was done and the Chisquared test was carried out. 


\section{Results}

During the year of the antimicrobial residue control, the incidence of "positives" ("positive and doubtful" responses) after the initial analysis by Eclipse "100ov" ${ }^{\circledR}$ was $2.6 \%$. Study by means of a logistic regression model to evaluate the effects of factors such as the seasonality, the composition, the SCC or the bacteriology on test results was used.

The application of the logistic regression model only considered the effect of the month of collection to be significant (table 1). The prediction model for calculating the frequencies of "positive" samples, taking into account the month of collection was:

$$
\mathrm{L}=-2.8813-0.1028 \mathrm{~T}^{2}+0.0159 \mathrm{~T}^{3}-0.00064 \mathrm{~T}^{4}
$$

The results of the Goodness-of-Fit Test for this logistic regression model showed a Chisquared of $1.7236 ; \mathrm{p}=0.6317$, as the value $p$ is superior to 0.1 , there is no reason to reject the adaptation of the adjusted model to a level of confidence of $90 \%$ and over.

Figure 1 represents the relative frequencies of "positive" responses by the Eclipse "100ov" ${ }^{\circledR}$ test and the percentages of "positive" cases calculated by using the coefficients obtained with this logistic model. In this figure the highest frequencies can be seen in summer and early autumn. Samples which were "positive" after the initial analysis were confirmed by heating at $82^{\circ} \mathrm{C}$ for $10 \mathrm{~min}$. After this heat treatment the outcome of "positives" was $0.9 \%$. As with the initial assay, the effect of the month collection variable was now the only significant variable (table 2). The mathematic 
equation which estimates the frequency of "positive" cases for the Eclipse "100ov" "® method was:

$$
\mathrm{L}=-9.4844+4.131 \mathrm{~T}-1.0083 \mathrm{~T}^{2}+0.0928 \mathrm{~T}^{3}-0.00288 \mathrm{~T}^{4}
$$

The Goodness of Fit Test showed a Chi-squared of 4.3429 and $p=0.2267(90 \%$ of confidence interval). By applying the logistic regression model (figure 1) the highest frequencies of "positive" results were presented in September and October.

The twenty-six samples that were confirmed after heating as "positive" were analysed by the tests of the penicillinase and PABA solutions (table 3). Most of them (19 samples) did not react positively with any of the two assessments, six samples reacted positively to penicillinase solution, and one sample could not be identified because of a dilution effect.

The second part of this work aims to compare the results obtained by the Eclipse "100ov" test with those obtained by the Delvotest $\mathrm{SP}^{\circledR}$ method, a method recognised by the Association of Official Analytical Chemists (AOAC 2004). Table 4 shows the results after the simultaneous analysis of raw milk samples by both methods. At the initial assay, a total of 101 samples were "positive" to Delvotest $\mathrm{SP}^{\circledR}$ whereas only 71 were "positive" to Eclipse "100ov" " , of which only 46 were "positive" in both tests. The heat treatment reduced the number of "positive" samples to 47 and 26 for Delvotest $\mathrm{SP}^{\circledR}$ and Eclipse “100ov" ${ }^{\circledR}$, respectively (table 5). But, only 17 samples were "positive" in both methods. The two analyses (initial and after heating) showed a higher detection of "positive" samples by the Delvotest $\mathrm{SP}^{\circledR}$ method than by the Eclipse "100ov" ${ }^{\circledR}$. On 
the other hand, of the 17 samples that were "positive" by both methods, 10 samples corresponded to unidentified samples, 6 samples were "positive" to penicillinase solution and 1 sample was associated with a dilution effect when penicillinase and PABA solutions were assayed by both methods (data not showed).

In both methods the effect of the heat treatment showed a high number of "positive" samples at the initial assay (54 for the Delvotest $\mathrm{SP}^{\circledR}$ and 45 for the Eclipse " $100 \mathrm{ov}{ }^{\circledR}$ ), which turned negative after heating (from now on "false positives"). When the "positives" and "false positives" that were detected simultaneously by the two methods were compared, only 5 coincided with a "false positive" result (table 6). Relative frequencies of "false positives" observed by both methods are shown in figure 2.

\section{Discussion}

After the heat treatment of the samples, the ratio of positives detected by Eclipse "100ov" ${ }^{\circledR}$ test in this study lowered to $1 \%$. The control of the same samples by the Delvotest $\mathrm{SP}^{\circledR}$ showed a slightly higher level (1.7\%; Yamaki et al. 2004). With regards to these levels of antimicrobial residues, the quality of ewe milk destined for the production of Manchego cheese with PDO seems to be more suitable than the ones reported by other studies in ewe milk (Esnal et al. 2002, Continanza et al. 2003, Herrera et al. 2004) which showed higher percentages of positive cases. Manchego cheese is the most important Spanish PDO cheese (MAPYA 2002b), and the strict control of milk destined to its elaboration has to be the first requirement to guarantee, not only certification, but also a safe product. The hygienic-sanitary quality of Manchega ewe milk has undergone improvements over the last few years (Pérez-Guzmán et al. 2000), mainly assisted by the regular monitoring of some hygienic-sanitary parameters (SCC 
or bacteria content) carried out by the sanitary authorities and the Manchega Breed Association (Gallego 2002). This fact could have had an important influence on a better sanitary status of the mammary gland by reducing the use of antibiotic therapy, and consequently, the number of residues in ewe milk. However, this incidence is still almost ten fold more than in cow milk (FDA/CFSAN 2001, Suhren and Reichmuth 2003), and sampling plans to control residues in ewe milk may continue in order to reduce the presence of antimicrobial residues even more.

A lower number of "positives" were detected when the samples were assayed by the Eclipse "100ov" ${ }^{\circledR}$, compared to the Delvotest $\mathrm{SP}^{\circledR}$. The sensitivity of these tests is an important factor to be considered in order to interpret the lower level of residues detected by Eclipse “100ov" ${ }^{\circledR}$. Althaus et al. (2002) and Montero et al. (2005) have studied the sensitivity of both methods for several antibiotics in ewe milk. Because the Eclipse "100ov" ${ }^{\circledR}$ test shows worse detection limits than the Delvotest $\mathrm{SP}^{\circledR}$ for several antibiotics (Althaus et al. 2002, Montero et al. 2005), it is probable that the Delvotest $\mathrm{SP}^{\circledR}$ detected positives samples which contained lower concentrations of some antibiotics. According to these authors, sulphonamides or tetracyclines showed similar detection limits for both methods, while some antimicrobial groups such as $\beta$-lactams, aminoglycosides or macrolides could perhaps be underestimated when ewe milk is assayed by the Eclipse "100ov" (Althaus et al. 2002, Montero et al. 2005). Six of the samples confirmed as positives by the Eclipse "100ov" ${ }^{\circledR}$ were identified by means of the penicillinase solution as $\beta$-lactams (table 3), and these samples were also identified as $\beta$-lactams by the Delvotest $\mathrm{SP}^{\circledR}$ test. The number of samples identified as $\beta$-lactams by the Delvotest $\mathrm{SP}^{\circledR}$ (14; Yamaki et al. 2004) was higher than those observed by the 
Eclipse "100ov" ${ }^{\circledR}(6)$, probably due to a higher sensitivity for these compounds (Althaus et al. 2002), even under the legal limits established by the European Union normative. On the other hand, there are a great number of "positive" samples by Eclipse "100ov" $"$ (table 2) that were not identified as $\beta$-lactams or sulphonamides. Therefore, aminoglycosides, macrolides, tetracyclines, quinolones, or other antimicrobials different to $\beta$-lactams or sulphonamides could be presented in this group. Esnal et al. (2003) detected $\beta$-lactams, tetracyclines and macrolides by using a microbiological multiplate system to confirm residues in ewe milk. According to these authors these substances are commonly used for ovine mastitis therapy in Spain. For this reason it could be interesting to go more deeply into the detection of these substances using chromatographic methods (HPLC or HPLC-Mass Spectrometry), that are able to detect and correctly quantify these substances.

On the other hand both methods showed a high number of "false positives" even though from the point of view of percentages, the number of "false positives" detected by the Eclipse " $100 \mathrm{ov}$ " ${ }^{\circledR}$ method was higher than those observed with the Delvotest $\mathrm{SP}^{\circledR}$, as $63 \%$ of the positive samples of the Eclipse "100ov" ${ }^{\circledR}$ turned out to be "false positives" and $53 \%$ in the case of the Delvotest $\mathrm{SP}^{\circledR}$ method. Several authors have related "false positives" with the presence of natural inhibitors, SCC, micro-organisms, or free fatty acids (Carlsson et al. 1989, Van Eenennaam et al. 1993, Andrew et al. 1997, Kang and Kondo 2001). Some naturally occurring compounds, such as the lactoperoxidase system, the lactoferrin or the lysozyme, could have an important negative effect on the growth of the bacteria indicators used in microbiological assays by showing "false positive" results, mainly due to their antimicrobial activity (Carlsson et al. 1989, 
Wolfson and Summer 1993). The enzymatic nature of these compounds favours their inactivation by heating, and consequently the diminution of erroneous responses. The effect of heating on the response of Delvotest $\mathrm{SP}^{\circledR}$ has been previously reported in cow and ewe milk (Kang and Kondo 2001, Molina et al. 2003b). The same took place with this method. The heat treatment of ewe milk at $82^{\circ} \mathrm{C}$ for 10 min decreased the number of positive samples detected by Eclipse " $100 \mathrm{ov}$ " ${ }^{\circledR}$ test. This fact suggests the need to heat samples previous to analysis. However, these samples could also contain antimicrobial thermosensitive substances which justified this reduction (Moats 1999, Zorraquino et al. 2005).

In this trial, antimicrobial residue violations seemed to occur more in late summer and early autumn. The main results of the simultaneous assay with the Delvotest $\mathrm{SP}^{\circledR}$ test have been published by Yamaki et al. (2004), and showed that a significant higher incidence has been also observed in these months (Yamaki et al. 2004), mainly with regards to "false positives". This fact has been related to out-of-season breeding practices on Manchega ewes. The Manchega breed showed a lower seasonality in its reproductive performance, this allows more reproductive periods during the year. Generally, the months of July and August coincided with the last part of the ewes' lactation period, at this time the content of natural inhibitors and SCC is higher (Gonzalo et al. 1994, Bergonier et al. 2003), which could provoke a higher level of "false positives".

The highest level of "positives" was observed from July to November. This period coincides with the final lactation of the animals who gave birth in January and February 
and when the milking period of out-of-season breeding animals starts. In these periods the milk production is lower with a concentration effect taking place in the milk (Gallego 2002; Pérez-Guzmán et al. 2000), this probably favours the concentration of antibiotics in the milk. In this study a lower level of milk production was observed (data not shown), which could explain the high number of positives detected.

The Eclipse "100ov" ${ }^{\circledR}$ is a screening test based on microbial inhibition principles which has been developed for assaying ewe milk. The number of positives detected with this test was lower than those observed with Delvotest $\mathrm{SP}^{\circledR}$ test, as much in the initial analysis (table 4) as in the confirmation after heating (table 5). Sischo and Burns (1993) defined the term "specificity" as "the relation between the number of negative results and the total number of samples analysed by means of a determined method, using residue-free milk", and related it with "false positive" results. The specificities for Delvotest $\mathrm{SP}^{\circledR}$ and Eclipse “100ov" ${ }^{\circledR}$ methods were previously estimated at $97.7 \%$ and 99\%, respectively (Molina et al. 2003b; Montero et al. 2005).

Factors such as the chemical composition, physiological aspects, or hygienic-sanitary parameters (SCC and microbial level), could have an important influence on the detection of "false positive" results by microbiological tests (Althaus et al. 2003, Molina et al. 2003b). In this study, none of these factors seemed to interfere in the response of the Eclipse "100ov" ${ }^{\circledR}$ test, as the logistic regression results show (tables 1 and 2). By contrast, other tests suffer more interference due to some of these factors, which have been observed in other studies carried out in ewe milk (Althaus et al. 2003, Molina et al. 2003b, Yamaki et al. 2004). This test has been specifically developed to 
be used in ewe milk, and some interference due to the intrinsic or extrinsic characteristics of ewe milk could have been solved by the manufacturer. Therefore, the detection of "false positive" cases should be lower in ewe milk. However, a slightly higher number of "false positives" has been detected with the Eclipse "100ov" ${ }^{\circledR}$ method which could be attributed to a greater sensitivity when faced with natural inhibitors. This factor has not been analysed in this study.

\section{Conclusions}

In general, the Eclipse "100ov" ${ }^{\circledR}$ method detected a slightly lower number of positive samples than the Delvotest $\mathrm{SP}^{\circledR}$ and a slightly higher number of "false positives". The results obtained by the Eclipse "100ov" ${ }^{\circledR}$ test indicated that approximately $99 \%$ of the ewe milk assayed in Castilla-La Mancha region (Spain) destined to Manchego PDO cheese production is appropriate for human consumption. Regardless of the seasonality, none of the variables studied (composition, SCC or bacteriology) seemed to have an influence on the response of this method. Among the positive samples, 25\% corresponded to $\beta$-lactam substances, but a preponderance of unidentified substances was appreciated. Therefore, it is necessary to make an effort to increase the knowledge of the presence of residues in ewe milk at a screening level to guarantee food safety.

\section{Acknowledgements}

This work was funded by project 191/IA-40, from the Consejeria de Agricultura y Medio Ambiente (Junta de Comunidades de Castilla-La Mancha, Spain). The authors would like to thank the workers from the Forlactaria Operadores Lecheros S.A. dairy company (Villarrobledo, Albacete, Spain) for their valuable help in the collection of 
samples. The authors are also grateful to ZEU-Inmunotec (Zaragoza, Spain) for their support.

\section{References}

ASSOCIATION OF OFFICIAL ANALYTICAL CHEMISTS., 2004, Antibiotic and Veterinary Drug Residues Test Kits. Available online at: www.aoac.org/testkits/certificates/930704.pdf (accessed 25 November 2004).

AGRESTI, A. (Ed.), 1990, Categorical data analysis (New York: John Wiley and Sons).

ALTHAUS, R.L., PERIS, C., MONTERO, A., and MOLINA, M.P., 2002, Detection limits of antimicrobials in ewe milk by Delvotest. Milchwissenschaft, 57, 660-664.

ALTHAUS, R.L., TORRES, A., PERIS, C., BELTRÁN, M.C., FERNÁNDEZ, N., and MOLINA, P., 2003, Accuracy of BRT and Delvotest microbial inhibition tests by composition of ewes milk. Journal of Food Protection, 66, 473-478.

ANDREW, S.M., FROBISH, R.A., PAAPE, M.J., and. MATURIN, L.J., 1997, Evaluation of selected antibiotic residue screening tests for milk from individual cows and examination of factors that affect the probability of false-positive outcomes. Journal of Dairy Science, 80, 3050-3057.

BARBOSA, M., SUHREN, G., and BEUKERS, R., 2004, Suitability and Application of Available Test Kits for the Detection of Residues of Antimicrobials in Milk from Species Other than the Cow - a Review. IDF Bull No., 390, 12 pp.

BERGONIER, D., and BERTHELOT, X., 2003, New advances in epizootiology and control of ewe mastitis. Livestock Production Science, 79, 1-16. 
CARLSSON, A., BJORCK, L., and PERSSON, K., 1989, Lactoferrin and lysozyme in milk during acute mastitis and their inhibitory effect in Delvotest P. Journal of Dairy Science, 72, 3166-3175.

CONTINANZA, R.M., TIBURTINI, S., and PAGGI, U., 2003, Determinazione di inibenti nel latte mediante kit microbiologico. Il latte, 28 (4), 80-84.

EC, 1992, Council Directive (EC) 92/46 of 16 June 1992 laying down the health rules for the production and placing on the market of raw milk, heat-treated milk and milk-based products. Official Journal of the European Communities, L 268, pp. 1824.

EC, 1996, Council Directive (EC) 96/23 of 29 April 1996 on measures to monitor certain substances and residues thereof in live animals and animal products and repealing Directives 85/358/EEC and 86/469/EEC and Decisions 89/187/EEC and 91/664/EEC. Official Journal of the European Communities, L 125, pp. 10-32.

EC, 1997, Commission Decision (EC) No 97/747 of 27 October 1997 fixing the levels and frequencies of sampling provided for by Council Directive 96/23/EC for the monitoring of certain substances and residues thereof in certain animal products. Official Journal of the European Communities, L 303, pp. 12-15.

ESNAL, A., GAMALlO, J.A., MARCO, J.C., RODRÍGUEZ, L., SOPENA, J., MARTINEZ, F., DEL REAL, M.A., GARCÍA, I., ORDÓÑEZ, J., MARTÍN, S., and EXTRAMIANA, A.B., 2002, Valoración práctica de un estudio de inhibidores y de recuento de patógenos contagiosos en leche de tanque de cuatro agrupaciones de productores de leche de oveja. Proceedings of the VI Jornadas Internacionales de la Sociedad Española de Ovinotecnia y Caprinotecnia, 19-21 September, Valencia, Spain, edited by SEOC (Valencia, Spain), pp 576-582. 
FAOSTAT, 2004, Datos Agrícolas de FAOSTAT. Available online at: www.faostat.fao.org/faostat/collections?version=extandhasbulk=0andlanguage $=\mathrm{ES}$ (accessed 10 December 2004),

FOOD AND DRUG ADMINISTRATION/CENTER FOR FOOD SAFETY AND APPLIED NUTRITION, 2001, National Milk Drug Residue Data Base Fiscal Year 2000 Annual Report, Available online at: www.vm.cfsan.fda.gov/ ear/milkrp00.html (accessed 4 May 2004).

GALLEGO, R., 2002, Análisis de estructuras y sistemas de producción en el sector del ganado ovino Manchego. Available online at: www.libroblancoagricultura.com/libroblanco/jautonomica/c_mancha/comunicacion es/gallego.pdf (accessed 12 January 2005).

GONZALO, C., CARRIEDO, J.A., BARO, A., and PRIMITIVO, F.S., 1994, Factors influencing variation of test day milk yield, somatic cell count, fat, and protein in dairy sheep. Journal of Dairy Science, 77, 1537-1542.

HERRERA, E., ABECIA, J.A., and MARTíN, S., 2004, Antibióticos en leche de tanque. Albéitar, 75, 54-55.

KANG, J-H., and KONDO, F., 2001, Occurrence of false-positive results of inhibitor on milk samples using the Delvotest SP assay. Journal of Food Protection, 64, 12111215.

MINISTERIO DE AGRICULTURA, PESCA Y ALIMENTACIÓN, 2002a, Anuario de estadística agroalimentaria. Available online at: www.mapya.es/estadistica/Anu_02/pdf/PDF21_09.pdf (accessed 11 March 2004).

MINISTERIO DE AGRICULTURA, PESCA Y ALIMENTACIÓN, 2002b, Datos de las Denominaciones de Origen Protegidas (D.O.P.) e Indicaciones Geográficas 
Protegidas (I.G.P.) de productos agroalimentarios. Available online at: www.mapya.es/alimentacion/pags/denominacion/documento/Agroalimentarios2002. pdf (accessed 11 March 2004).

MOATS, W.A., (Ed.), 1999. The effect of processing on veterinary residues in foods. In: Impact of processing on Food Safety. (New York: Kluwer Academic Plenum Publishers) p 233.

MOLINA, M.P., ALTHAUS, R.L., MOLINA, A., and FERNÁNDEZ, N., 2003a, Antimicrobial agent detection in ewes' milk by the microbial inhibitor test brilliant black reduction test - BRT AiM ${ }^{\circledR}$. International Dairy Journal, 13, 821-826.

MOLINA, M.P., ALTHAUS, R.L., BALASCH, S., TORRES, A., PERIS, C., and FERNÁNDEZ, N., 2003b, Evaluation of screening test for detection of antimicrobial residues in ewe milk. Journal of Dairy Science, 86, 1947-1952.

MONTERO, A., ALTHAUS, R.L., MOLINA, A., BERRUGA, I., and MOLINA, M.P., 2005, Detection of antimicrobial agents by a specific microbiological meted (Eclipse $100^{\circledR}$ ) for ewe milk. Small Ruminant Research, 57, 229-237.

PÉREZ-GUZMÁN, M.D., OLIVER， F., GALLEGO, R., GARCÍA, M., and MONTORO, V., 2000, Recuentos de células somáticas en leche de tanque de ganaderías de raza ovina Manchega durante los años 1992-1999. ILE, may, 32-34.

STATGRAPHICS. 1997. Statgraphics Plus, version 5.1, user manual. Rockville MD: Manugistics, Inc.

SISCHO, W.M., and BURNS, C.M., 1993, Field trial of four cowside antibiotic screening test. Journal of the American Veterinary Medical Association, 202, 12491254.

SUHREN, G., REICHMUTH, J., and WALTE, H.G., 1996, Detection of $\beta$-lactam antibiotics in milk by the Penzym-test. Milchwissenschaft, 51, 269-273. 
SUHREN, G., and REICHMUTH, J., 2003, Messbarkeit und Entwicklung der hygienischen Wertigkeit des Rohstofs Milch. Kieler Milchwirtschaftliche Forschungsberichte, 55, 5-36.

Van EENENNAAM, A.L., CULlOR, J.S., PERANI, L., GARDNER, I.A., SMITH, W.L., DELLINGER, J., and GUTERBOCK, W.M., 1993, Evaluation of milk antibiotic residue screening tests in cattle with naturally occurring clinical mastitis. Journal of Dairy Science, 76, 3041-3053.

WOLFSON, L.M., and SUMMER, S.S., 1993, Antibacterial activity of the lactoperoxidase system: A review. Journal of Food Protection, 56, 887-892.

YAMAKI, M., BERRUGA, M.I., ALTHAUS, R.L., MOLINA, M.P., AND MOLINA, A., 2004, Occurrence of antibiotic residues in milk from Manchega Ewe Dairy Farms. Journal of Dairy Science, 87, 3132-3137.

ZORRAQUINO, M.A., 2005, Inactivación térmica de sustancias antimicrobianas en la leche. Tesis Doctoral. Universidad Publica de Navarra. España. 140 pp. 